\title{
Profile of omalizumab in the treatment of chronic spontaneous urticaria
}

This article was published in the following Dove Press journal:

Drug Design, Development and Therapy

25 August 2015

Number of times this article has been viewed

\section{Moises Labrador-Horrillo' Marta Ferrer ${ }^{2}$}

'Allergy Section, Internal Medicine Department, Vall d'Hebron Hospital, Universitat Autònoma de Barcelona, Barcelona, ${ }^{2}$ Department of Allergy and Clinical Immunology, Clínica Universidad de Navarra, IDISNA, Instituto de Investigación de Navarra, Pamplona, Spain
Correspondence: Moises LabradorHorrillo

Allergy Section, Internal Medicine Department, Vall d'Hebron Hospital, Passeig Vall d'Hebron, I 19-129, 08035 Barcelona, Spain

Tel/fax +34932746169

Email mlabrador@vhebron.net
Abstract: Chronic spontaneous urticaria (CSU) is a disease with significant morbidity and relative prevalence that has important effects on the quality of life (QoL) of those who suffer from it. Omalizumab is a recombinant humanized anti-immunoglobulin E ( $\mathrm{IgE}$ ) antibody that binds to the C 33 domain of the IgE heavy chain and prevents it from binding to its high-affinity receptor FceRI. It has been largely studied in the field of asthma and is currently approved for the treatment of both adult and pediatric (children; $>6$-year-old) patients. In addition, in recent, well-controlled clinical trials in patients with CSU resistant to antihistamines, add-on therapy with subcutaneous omalizumab significantly reduced the severity of itching, and the number and size of hives, and increased patients' health-related QoL and the proportion of days free from angioedema compared with placebo, with an excellent tolerance. Thus, omalizumab is an effective and well-tolerated add-on therapy for patients with CSU who are symptomatic despite background therapy with $\mathrm{H} 1$ antihistamines. In this review, we cover the following points: epidemiology, pathogenesis, assessment of activity, impact on QoL, and treatment of CSU, and finally, we focus on omalizumab in the treatment of CSU including the pharmacokinetic properties and mechanism of action, and use in pregnant women, nursing infants, and children.

Keywords: omalizumab, chronic spontaneous urticaria, antihistamines, subcutaneous administration, add-on therapy

\section{Introduction}

Urticaria is a disease characterized by the development of wheals (hives) or angioedema, or both, with associated intense pruritus. Individual lesions last less than 24 hours with the skin returning to its normal appearance, usually within 1-24 hours. Most episodes last less than 6 weeks and are diagnosed as acute urticaria; chronic urticaria (CU) is defined as wheals or angioedema, or both, occurring intermittently or continuously for at least 6 weeks. This disease has a major impact on the quality of life (QoL) of those patients affected with an effect on both objective functioning and subjective well-being. CU has been further classified into different subtypes: spontaneous and inducible by physical stimuli (Table 1). The terms chronic spontaneous urticaria (CSU) and chronic idiopathic urticaria (CIU) are used interchangeably in the scientific papers. The joint initiative of the Dermatology Section of the European Academy of Allergy and Clinical Immunology (EAACI), the EU-funded network of excellence, the Global Allergy and Asthma European Network (GA² LEN), the European Dermatology Forum (EDF), and the World Allergy Organization (WAO) in the EAACI/GA ${ }^{2} \mathrm{LEN} /$ EDF/WAO guideline published in 2014, as well as the British Society for Allergy and Clinical Immunology (BSACI) guideline for the management of CU prefers the use of the term CSU because it implies an underlying endogenous cause. ${ }^{1,2}$ The Joint Task Force on Practice Parameters (JTFPP), representing the American Academy 
Table I Chronic urticaria subtypes

\begin{tabular}{ll}
\hline Spontaneous & Inducible (physical urticaria) \\
\hline Chronic spontaneous urticaria & Urticaria factitia, dermographic urticaria \\
Chronic autoimmune urticaria & Cold urticaria \\
& Delayed pressure urticaria \\
& Solar urticaria \\
& Heat urticaria \\
& Vibratory angioedema \\
& Cholinergic urticaria \\
& Contact urticaria \\
& Aquagenic urticaria \\
\hline
\end{tabular}

of Allergy, Asthma and Immunology, the American College of Allergy, Asthma and Immunology, and the Joint Council of Allergy, Asthma and Immunology still continue to use CIU. ${ }^{3}$

Omalizumab is a recombinant humanized antiimmunoglobulin $\mathrm{E}$ ( $\operatorname{IgE}$ ) antibody that binds to the CE3 domain of the IgE heavy chain. It has been largely studied in the field of asthma and is currently approved for the treatment of both adult and pediatric (children; $>6$-year-old) patients. The presence of $\operatorname{IgG}$ anti-alpha subunit of the $\operatorname{IgE}$ receptor has been demonstrated in a portion of patients with CSU. ${ }^{4}$ The rationale to employ omalizumab for controlling CSU was that the IgE binding with omalizumab causes internalization of the $\operatorname{IgE}$ receptor, and as a consequence, the disappearance of the autoantigen. However, omalizumab might have additional effects, since it is also effective in non-autoimmune urticaria. ${ }^{5}$

\section{Epidemiology of CSU}

The prevalence of CSU is unknown, but it is estimated to be $0.5 \%-1 \%$ of the population, and the annual incidence is estimated at $1.4 \%{ }^{1,3}$

In 2004, Gaig et al conducted a population-based study among adults in Spain to approach the real prevalence of CU. ${ }^{6}$ They found a prevalence of $0.6 \%$ with a predominance of $\mathrm{CU}$ in women (odds ratio $=3.82$ ) and reported that approximately $80 \%$ of patients were symptom-free after 1 year, and symptoms last from 1 year to 5 years in $8.7 \%$ and for more than 5 years in $11.3 \%{ }^{6}$

\section{Pathogenesis of CSU}

While the pathogenesis of CSU has been extensively investigated, no theory has been conclusively proven, and a combination of mechanisms may play a role.

Vasoactive mediators released from mast cells and basophils play a key role in the pathogenesis of CSU. Despite the presence of other mediators (eicosanoids, cytokines, and proteases), histamine is the most prominent and acts on $\mathrm{H} 1$ receptors (85\%) and $\mathrm{H} 2$ receptors (15\%) in the skin. While histamine binding to $\mathrm{H} 1$ receptors leads to pruritus (by stimulation of C fibers), binding to receptors on postcapillary venules induces vasodilation, increased vascular permeability, and edema. ${ }^{\text {? }}$

Mechanisms other than histamine release have been implicated in CSU and include abnormalities in basophil signal transduction and number, and autoimmunity. Intradermal injection of autologous plasma and/or sera from some patients with CSU causes a wheal and flare reaction; this test is named autologous serum skin test and could reflect the presence of histamine-releasing autoantibodies. Different autoantibodies can be found in up to $45 \%$ of patients with CSU. These autoantibodies can be targeted at the IgE (Fc portion), the high-affinity IgE receptor (FceRI), and also the antithyroid autoantibodies (both anti-microsomal and anti-thyroperoxidase) ${ }^{8}$

There is also increasing evidence of altered number, structure, function of basophils, and defects in their trafficking. Basopenia is well documented, and basophil numbers are inversely related to urticaria severity. ${ }^{9}$ Numerical and behavioral alterations in basophils complemented by changes in signaling molecule expression and function as well as aberrant activation of extrinsic pathway of coagulation are other alternative hypotheses. ${ }^{10}$

\section{Assessment of activity of CSU and impact on QoL}

Disease activity in CSU may be assessed with the "Urticaria Activity Score” during 7 days (UAS7) (Table 2). This tool is a unified and simple scoring system that was proposed in the last version of the guidelines and has been validated in many languages. ${ }^{11}$ For patients with associated angioedema, a novel activity score, the Angioedema Activity Score, has been developed and validated by the group of Professor Maurer in Berlin. ${ }^{12}$ It is important, in addition to disease

Table 2 Urticaria Activity Score 7 (UAS7): a validated tool with which to follow disease activity in clinical practice

\begin{tabular}{|c|c|c|}
\hline Score & Wheals & Pruritus \\
\hline 0 & None & None \\
\hline I & $\begin{array}{l}\text { Mild }(<20 \\
\text { wheals } / 24 \text { hours) }\end{array}$ & $\begin{array}{l}\text { Mild (present but not annoying or } \\
\text { troublesome) }\end{array}$ \\
\hline 2 & $\begin{array}{l}\text { Moderate }(20-50 \\
\text { wheals/24 hours) }\end{array}$ & $\begin{array}{l}\text { Moderate (troublesome but does } \\
\text { not interfere with normal daily } \\
\text { activity or sleep) }\end{array}$ \\
\hline 3 & $\begin{array}{l}\text { Intense }(>50 \\
\text { wheals } / 24 \text { hours) }\end{array}$ & $\begin{array}{l}\text { Intense (severe pruritus, which is } \\
\text { sufficiently troublesome to interfere } \\
\text { with normal daily activity or sleep) }\end{array}$ \\
\hline
\end{tabular}

Note: Sum of score: 0-6 for each day is summarized over I week (maximum 42). 
activity, to assess the impact of disease on QoL of urticaria patients both in clinical care and in trials. Although specific dermatological skin disease questionnaires have been used in CU, a specific questionnaire, the CU-Q2oL, was designed in $2005^{13}$ consisting of 23 questions or items grouped into six QoL categories associated with the disease: itch (two questions), swelling (two questions), impact on daily activities (six questions), sleep problems (five questions), limitations (three questions), and looks (five questions). It has been shown to be reproducible and sensitive to change, and has been validated in several language versions. ${ }^{14}$ Recently, attempts have been made to combine these evaluations to create a specific tool that would enable us to simultaneously evaluate the severity of the condition and the impact of symptoms on QoL. One such tool is the Urticaria Control Test (UCT). This tool has four items, and each item has five answer options (scored with $0-4$ points). Low points indicate high disease activity and low disease control. Accordingly, the minimum and maximum UCT scores are 0 and 16 , respectively, with 16 points indicating complete disease control. This tool also allows us to compare global changes brought about by different treatments. ${ }^{15}$ It would be of interest in the future to explore the utility of other disease score dermatology tools as Chromameter, DermaSpectrometer, or Skin-Visiometer ${ }^{\circledR}$ for CSU.

\section{Treatment of $\mathrm{CU}$}

Recent guidelines, EAACI/GA ${ }^{2}$ LEN/EDF/WAO, ${ }^{1}$ JTFPP, ${ }^{3}$ and $\mathrm{BSACI},{ }^{2}$ recommend a step-by-step approach to the management of CSU (Table 3). Disease activity and QoL should be properly assessed in every stage. Identification and elimination or avoidance of the triggers stimulus or aggravating factors of the CSU should also be performed. First-line pharmacotherapy in CSU consists of modern nonsedating, second-generation $\mathrm{H} 1$ antihistamines. ${ }^{1-3} \mathrm{H} 2$ antihistamines may also be used in addition to the first-generation antihistamines. Sedating, first-generation $\mathrm{H} 1$ antihistamines which have been used during years in clinical practice for CSU are considered at bed time as a second-line addition and only in the American guideline. ${ }^{3}$ Sedating, first-generation H1 antihistamines are excluded in the European guidelines. ${ }^{1,2}$ All guidelines recommend dose escalation (up to fourfold) of the chosen antihistamine as a second-line option, although the British and American guidelines also recommend adding a second antihistamine. Omalizumab is considered a third-line treatment option in the European guidelines. ${ }^{1,2}$ The American guideline includes omalizumab as a fourth-line option, stressing that the benefits need to be weighed against the cost burden. ${ }^{3}$ Omalizumab has been approved in March 2014 by the US Food and Drug Administration (FDA) and by European Medicines Agency (EMA) and in August 2014 by Heath Canada for use in adults and children aged 12 years and above with CSU refractory to $\mathrm{H} 1$ antihistamines. ${ }^{16,17}$ The approval of omalizumab for this indication is based on the results published from two cardinal Phase III clinical trials known as ASTERIA II and GLACIAL. A third Phase III clinical trial named ASTERIA I also shows the same efficacy. ${ }^{18-20}$

\section{Omalizumab in the treatment of CSU}

Omalizumab is a recombinant humanized anti-IgE antibody that binds to the $\mathrm{C} \varepsilon 3$ domain of the $\operatorname{IgE}$ heavy chain where $\operatorname{IgE}$

Table 3 Recommended pharmacotherapy algorithms for chronic spontaneous urticaria (or chronic idiopathic urticaria)

\begin{tabular}{|c|c|c|}
\hline EAACI/GA²LEN/EDF/WAO' & JTFPP $^{3}$ & $\mathrm{BSACl}^{2}$ \\
\hline $\begin{array}{l}\text { First line: modern second-generation } \\
\text { antihistamines }\end{array}$ & Step I: second-generation antihistamines & $\begin{array}{l}\text { Step I: second-generation } \\
\text { antihistamines }\end{array}$ \\
\hline $\begin{array}{l}\text { Second line: increase second-generation } \\
\text { antihistamine dosage up to fourfold }\end{array}$ & $\begin{array}{l}\text { Step 2: one or more of the following: } \\
\text { dose advancement of second-generation } \\
\text { antihistamine, add another second- }\end{array}$ & $\begin{array}{l}\text { Step 2: increase second-generation } \\
\text { antihistamine dosage up to fourfold } \\
\text { or add a second antihistamine }\end{array}$ \\
\hline
\end{tabular}

generation antihistamine, add $\mathrm{H} 2$ antagonist, add leukotriene receptor antagonist, or add first-generation antihistamine at bedtime

Third line: add omalizumab or ciclosporin A or montelukast
Short course (up to 10 days) of corticosteroids may be used for exacerbations as needed
Step 3: dose advancement of potent

antihistamine (eg, hydroxyzine or doxepin)

as tolerated

Step 4: add alternative agent: omalizumab or cyclosporine, other anti-inflammatory agents, immunosuppressants, or biologics
Step 3: consider an anti-leukotriene agent

Step 4: consider an immunomodulant (eg, omalizumab, cyclosporine)

A short course of corticosteroids may be appropriate in severe episodes at any stage

Abbreviations: EAACI, European Academy of Allergy and Clinical Immunology; GA²LEN, Global Allergy and Asthma European Network; EDF, European Dermatology Forum; WAO, World Allergy Organization; JTFPP, Joint Task Force on Practice Parameters; BSACl, British Society for Allergy and Clinical Immunology. 
binds to its high-affinity receptor FceRI. It has been largely studied in the field of asthma and is currently approved for the treatment of both adult and pediatric (children; $>6$-year-old) patients with moderate-to-severe asthma. ${ }^{21-23}$

The original evidence of efficacy of omalizumab in CSU stemmed from several case series or small trials. ${ }^{5,24-28}$ Although many studies inferred that omalizumab is beneficial in CSU with a likely autoimmune etiology, ${ }^{25}$ other studies have demonstrated the efficacy of omalizumab in CSU irrespective of autoimmune status; in fact, a prospective study showed that omalizumab is an effective treatment for CSU patients with negative autoantibody assays against either IgE or its high-affinity receptor, who are resistant to antihistamines. $^{5}$

The first study that investigated optimal dosing of omalizumab in CU was a Phase II trial conducted by Saini et al in 2011 (ClinicalTrials.gov identifier: NCT00866788). This was a dose-ranging study named MYSTIQUE that assessed the efficacy of single-dose omalizumab $75 \mathrm{mg}, 300 \mathrm{mg}$, and $600 \mathrm{mg}$ compared with placebo over 4 weeks (plus 12 weeks of follow-up) in 90 adolescents and adults (aged 12-75 years) with CSU unresponsive to approved dosages of H1 antihistamines. The authors demonstrated that a single fixed dose of $300 \mathrm{mg}$ or $600 \mathrm{mg}$ of the drug (unlike in asthma where the dose is adjusted according to serum levels of $\operatorname{IgE}$ and patient weight) is a rapid and effective therapeutic option for patients who are symptomatic despite treatment with $\mathrm{H} 1$ antihistamines. $^{29}$

Later, the results of the three Phase III clinical trials have been reported. In the first trial, named ASTERIA II study (Clinicaltrials.gov identifier: NCT01292473), ${ }^{20}$ Maurer et al randomly assigned 323 patients (adults and adolescents aged $>12$ years) with persistent CSU despite treatment with $\mathrm{H} 1$ antihistamines at approved dose to receive $75 \mathrm{mg}$, $150 \mathrm{mg}$, or $300 \mathrm{mg}$ of omalizumab or placebo (three monthly subcutaneous [SC] injections during 12 weeks, followed by a 16-week follow-up period). The primary efficacy outcome of this study was the change from baseline in a weekly itch severity score (ISS) (this score ranges from 0 to 21 , with higher scores indicating more severe itching). The baseline weekly ISS was approximately 14 in all four study groups. After the treatment, the mean ( \pm standard deviation) change from baseline in the weekly ISS at week 12 was reduced to $-8.1 \pm 6.4$ in the $150 \mathrm{mg}$ group $(P=0.001)$ and to $-9.8 \pm 6.0$ in the $300 \mathrm{mg}$ group $(P<0.001)$ without reaching statistical significance in the $75 \mathrm{mg}$ group $(-5.9 \pm 6.5, P=0.46)$ and in the placebo group ( $-5.1 \pm 5.6)$. The rate of adverse events (AEs) was low and similar across the groups, although it was higher in the $300 \mathrm{mg}$ group (6\%) than in the placebo group (3\%) or in either the $75 \mathrm{mg}$ or the $150 \mathrm{mg}$ group (1\% for each). ${ }^{20}$

The second one is the study named GLACIAL (Clinicaltrials.gov identifier: NCT01264939). ${ }^{18}$ In this study, Kaplan et al evaluated the safety and efficacy of 24 weeks of treatment with omalizumab in 336 patients aged 12-75 years (18-75 years in Germany) with persistent CSU despite treatment with $\mathrm{H} 1$ antihistamines at up to four times the approved dose plus $\mathrm{H} 2$ antihistamines, leukotriene receptor antagonists, or both. In this study, the 336 patients were randomized to receive six SC injections at 4-week intervals of either $300 \mathrm{mg}$ of omalizumab or placebo, followed by a 16-week observation period. The primary objective of the study was to evaluate the overall safety of omalizumab compared with placebo. Efficacy was evaluated at weeks 12 and 24 and includes scores for itch severity, wheals, and urticaria activity. The overall incidence and severity of AEs were similar between omalizumab and placebo recipients. At week 12, the mean change from baseline in weekly ISS was 28.6 (95\% confidence interval, 29.3-27.8) in the omalizumab group compared with 24.0 (95\% confidence interval, 25.3-22.7) in the placebo group $(P<0.001)$. Significant improvements were seen in additional efficacy end points at week 12; these benefits were sustained to week 24 . Side effects were more likely to be reported in patients treated with the highest dose.

The last published study was named ASTERIA I (ClinicalTrials.gov identifier: NCT01287117). ${ }^{19}$ In this study, 319 patients aged 12-75 years with CSU who remained symptomatic despite treatment with approved doses of $\mathrm{H} 1$ antihistamines were randomized to receive SC placebo or omalizumab $75 \mathrm{mg}, 150 \mathrm{mg}$, or $300 \mathrm{mg}$ every 4 weeks for 24 weeks followed by 16 weeks of follow-up. The primary end point was change from baseline in weekly ISS at week 12. Efficacy results in ASTERIA I were similar to those from the other Phase III studies: ASTERIA II and GLACIAL.

The summary of all Phase III studies is that omalizumab significantly reduced symptoms in patients with CSU refractory to $\mathrm{H} 1$ antihistamines. Median time to response was shortest in the omalizumab $300 \mathrm{mg}$ group and suggests a relationship between omalizumab dose and time to onset. In these studies, there were no new safety concerns relative to the known tolerability profile of omalizumab derived from its use in treating allergic asthma. There were no anaphylactic reactions or clinically relevant changes in laboratory parameters. There were no anti-omalizumab antibodies detected at week 40 in the GLACIAL trial.

We have also collected data on the efficacy and safety of omalizumab in 110 patients from nine Spanish hospitals 
suffering from refractory CSU to available treatments in real-life practice, and the results are similar, even better than previously reported in controlled trials. Ninety (81.8\%) patients exhibited a complete or significant response, $12(10.9 \%)$ had partial response, and eight (7.2\%) showed no response. Sixty-six $(60 \%)$ patients were able to stop all concomitant medications, remaining asymptomatic treated with omalizumab alone. No serious AEs were reported. We did not find differences when we compared efficacy and time of response among different doses or scheduled protocols, even considering the different types of CSU included in the analysis and subanalysis (CSU with or without associated physical urticaria, CSU with angioedema, and chronic autoimmune urticaria patients). Of the 110 patients included, 41 discontinued use of omalizumab, 21 remained free of symptoms, and 20 required a reintroduction of the treatment. It is interesting to note that, in our series, omalizumab did not lose effectiveness upon reintroduction, and was equally effective again in 18 of the 20 patients in whom the drug was withdrawn. ${ }^{30}$ This effectiveness after reintroduction of omalizumab on CSU has also been recently reported by Metz et al. ${ }^{31}$

\section{Pharmacokinetic properties of omalizumab}

Omalizumab is a recombinant DNA-derived humanized monoclonal antibody produced in Chinese hamster ovary cells that selectively binds to human IgE. Xolair is a sterile, white, preservative-free lyophilized powder that is reconstituted with water for injections and administered as an $\mathrm{SC}$ injection. Prefilled syringe of $0.5 \mathrm{~mL}$ contains $75 \mathrm{mg}$ of omalizumab, and prefilled syringe of $1 \mathrm{~mL}$ contains $150 \mathrm{mg}$ of omalizumab. The solution for injection in prefilled syringe contains L-arginine hydrochloride, L-histidine hydrochloride, L-histidine, polysorbate 20, and water for injection as solvents. The average absolute bioavailability of omalizumab after $\mathrm{SC}$ administration is $62 \%$. Peak serum concentrations are obtained on average 6-8 days after SC administration of a single dose. The pharmacokinetics of omalizumab is linear at doses $(0.5 \mathrm{mg} / \mathrm{kg})$. The apparent volume of distribution is $78 \mathrm{~mL} / \mathrm{kg}$. Maximal suppression of free $\mathrm{IgE}$ in serum occurs 3 days after SC administration of omalizumab, and IgE levels remain suppressed throughout treatment with omalizumab administered every 4 weeks. Omalizumab is eliminated via the same processes as endogenous IgG, as well as via specific binding and complex formation with $\mathrm{IgE}$. IgG is habitually eliminated by the liver, principally by intracellular degradation following endocytosis (eg, by cells of the reticule endothelial system). Intact IgG is also eliminated in the bile. The terminal elimination half-life of omalizumab was estimated by population pharmacokinetic simulations to be 24 days at stable equilibrium, and the apparent clearance was $3 \mathrm{~mL} / \mathrm{kg} /$ day for a patient with an average weight of $80 \mathrm{~kg}$. Population pharmacokinetic modeling suggests that, in the treatment of patients with $\mathrm{CSU}$, there is no need for dosage adjustment based on age, race/ethnicity, sex, body weight, baseline $\operatorname{IgE}$ levels, autoantibodies to FceRI, or concomitant therapy with $\mathrm{H} 2$ antihistamines or leukotriene receptor antagonists. The pharmacokinetics of omalizumab has not been studied in CSU patients with renal or hepatic alterations. ${ }^{32}$

\section{Mechanism of action of omalizumab in CSU}

The mechanism of action of omalizumab in CSU has not yet been elucidated. Interestingly, the mechanism of omalizumab appears to be different in $\mathrm{CU}$ and allergic asthma, for which the drug has been previously approved. In CU, dosage is not dependent on serum IgE levels, and response is seen in a subset of CSU patients, quickly after only 12 hours. Omalizumab is likely to achieve its therapeutic effects in urticaria through diverse mechanisms. Omalizumab results in a significant and rapid reduction in serum levels of free IgE, with subsequent and late downregulation of FceRI ( $\operatorname{IgE}$ high-affinity receptor) and FceRII (IgE low-affinity receptor), as well as possible abduction of incoming allergen molecules and IgE immune complexes, which may abolish the ability of $\operatorname{IgE}$ to potentiate mast cell activity in this way. This may lead to nonspecific desensitization of mast cells and/or basophils in the skin, and thus explain the rapid therapeutic response seen in clinical practice..$^{33}$ In addition, omalizumab has been shown to downregulate not only $\mathrm{IgE}$ receptors on effector cells, including mast cells and basophils, but also dendritic cells. ${ }^{34}$ The latter effect suggests that blocking $\mathrm{IgE}$ can inhibit more chronic aspects of allergic inflammation involving T-cell activation. Moreover, omalizumab is thought to mediate some of its anti-inflammatory action by inducing apoptosis of eosinophils. ${ }^{35}$

Clearly though, the precise mechanisms by which omalizumab acts require further investigation.

\section{Omalizumab in pregnant women and nursing infants}

Omalizumab has been recently assigned to pregnancy category B by the FDA. Animal studies have failed to reveal evidence of maternal toxicity, embryotoxicity, or teratogenicity. There are no controlled data in human pregnancy. 
Recently, the Xolair Pregnancy Registry (EXPECT) has been published, ${ }^{36}$ in which 188 of 191 pregnant women were exposed to omalizumab (indicated by asthma) during their first trimester, with no apparent increased birth prevalence or patterns of major anomalies. Ninety-eight infants were also exposed to omalizumab while breastfeeding, with a median omalizumab exposure duration of 3.9 months without incidences. There are only few cases of use of omalizumab in CU pregnant women reported; 37,38 efficacy seems similar to that of the rest of $\mathrm{CU}$ patients (unpublished observations). Nevertheless, omalizumab is only recommended for use during pregnancy when potential benefit outweighs risk.

There are no data on the excretion of omalizumab into human milk. Animal studies realized by Genentech with cynomolgus monkeys have demonstrated milk levels that were $1.5 \%$ of maternal blood levels. IgG is excreted into human milk, and it is expected that omalizumab is also excreted. The effects in the nursing infant are unknown. The manufacturer (Genentech) recommends that caution be used when administering omalizumab to nursing women.

\section{Omalizumab in children with CSU}

There is very little published information on children suffering from CSU. ${ }^{39}$ To date, omalizumab has not been studied in children suffering from CSU aged $<12$ years. Accordingly, most of the recommendations contained in the current guidelines ${ }^{1-3}$ for the prevention and treatment of CSU in children are based on extrapolation of data obtained in Phase III clinical studies that included only adults and children above 12 years of age. ${ }^{18-20}$ The FDA and the EMA have approved omalizumab for the treatment of CSU only in children aged 12 years and above refractory to $\mathrm{H} 1$ antihistamines. ${ }^{16,17}$

\section{Conclusion}

Convincing evidence in support of the efficacy and safety of omalizumab in the treatment of CSU has accumulated over the past few years. Omalizumab has been shown to be an effective and well-tolerated add-on therapy in patients with CSU unresponsive to $\mathrm{H} 1$ antihistamines. There are several important questions regarding the use of omalizumab for the treatment of CSU that remain to be answered. Well-designed studies are needed to determine the patient profile most suitable for omalizumab treatment, the optimal duration of therapy, and rates of long-term remission. In addition, potential long-term side effects of omalizumab in the treatment of $\mathrm{CSU}$ require further investigation.

\section{Disclosure}

The authors are medical advisors of Novartis Spain (Group of Chronic Urticaria). All authors report no other conflicts of interest in this work.

\section{References}

1. Zuberbier T, Aberer W, Asero R, et al; European Academy of Allergy and Clinical Immunology; Global Allergy and Asthma European Network; European Dermatology Forum; World Allergy Organization. The EAACI/GA(2) LEN/EDF/WAO Guideline for the definition, classification, diagnosis, and management of urticaria: the 2013 revision and update. Allergy. 2014;67(7):868-887.

2. Powell RJ, Leech SC, Till S, Huber J, Nasser SM, Clark AT. BSACI guideline for the management of chronic urticaria and angiooedema. Clin Exp Allergy. 2015;45(3):547-565.

3. Bernstein JA, Lang DM, Khan DA, et al. The diagnosis and management of acute and chronic urticaria: 2014 update. J Allergy Clin Immunol. 2014; 133(5): 1270-1277.

4. Ferrer M, Kinét JP, Kaplan AP. Comparative studies of functional and binding assays for IgG anti-Fc(epsilon)RIalpha (alpha-subunit) in chronic urticaria. J Allergy Clin Immunol. 1998;101(5):672-676.

5. Ferrer M, Gamboa P, Sanz ML, et al. Omalizumab is effective in nonautoimmune urticaria. J Allergy Clin Immunol. 2011;127(5):1300-1302.

6. Gaig P, Olona M, Muñoz Lejarazu D, et al. Epidemiology of urticaria in Spain. J Investig Allergol Clin Immunol. 2004;14(3):214-220.

7. Viegas LP, Ferreira MB, Kaplan AP. The maddening itch: an approach to chronic urticaria. J Investig Allergol Clin Immunol. 2014;24(1):1-5.

8. Konstantinou GN, Asero R, Ferrer M, et al. EAACI taskforce position paper: evidence for autoimmune urticaria and proposal for defining diagnostic criteria. Allergy. 2013;68(1):27-36.

9. Grattan CEH, Dawn G, Gibbs S, Francis DM. Blood basophil numbers in chronic ordinary urticaria and healthy controls: diurnal variation, influence of loratadine and prednisolone and relationship to disease activity. Clin Exp Allergy. 2003;33(3):337-341.

10. Jain S, Sanjiv J. Pathogenesis of chronic urticaria: an overview. Dermatol Res Pract. 2014;12:59-74.

11. Młynek A, Zalewska-Janowska A, Martus P, Staubach P, Zuberbier T, Maurer M. How to assess disease activity in patients with chronic urticaria? Allergy. 2008;63(6):777-780.

12. Weller K, Groffik A, Magerl M, et al. Development, validation, and initial results of the Angioedema Activity Score. Allergy. 2013; 68(9):1185-1192.

13. Baiardini I, Pasquali M, Braido F, et al. A new tool to evaluate the impact of chronic urticaria on quality of life: chronic urticaria quality of life questionnaire (CU-QoL). Allergy. 2005;60(8):1073-1078.

14. Jáuregui I, Ortiz de Frutos FJ, Ferrer M, et al. Assessment of severity and quality of life in chronic urticaria. J Investig Allergol Clin Immunol. 2014;24(2):80-86.

15. Weller K, Groffik A, Church MK, et al. Development and validation of the Urticaria Control Test: a patient-reported outcome instrument for assessing urticaria control. J Allergy Clin Immunol. 2014;133(5):1365-1372.

16. US FDA. Xolair (Omalizumab): US Prescribing Information; 2003. Available from: http://www.accessdata.fda.gov/drugsatfda_docs/label/ 2014/103976s5211lbl.pdf

17. European Medicines Agency. Xolair $150 \mathrm{mg}$ Powder/Solution: Summary of Product Characteristics; 2014. Available from: http://www.ema.europa.eu/docs/en_GB/document_library/ EPAR_-_Product_Information/human/000606/WC500057298.pdf

18. Kaplan A, Ledford D, Ashby M, et al. Omalizumab in patients with symptomatic chronic idiopathic/spontaneous urticaria despite standard combination therapy. J Allergy Clin Immunol. 2013;132:101-109.

19. Saini SS, Bindslev-Jensen C, Maurer M, et al. Efficacy and safety of omalizumab in patients with chronic idiopathic/spontaneous urticaria who remain symptomatic on H1-antihistamines: a randomized, placebocontrolled study. J Invest Dermatol. 2014;2014:2-28. 
20. Maurer M, Rosén K, Hsieh HJ, et al. Omalizumab for the treatment of chronic idiopathic or spontaneous urticaria. N Engl J Med. 2013; 368(10):924-935.

21. Kopp MV. Omalizumab: anti-IgE therapy in allergy. Curr Allergy Asthma Rep. 2011;11(2):101-106.

22. Kuhl K, Hanania NA. Targeting IgE in asthma. Curr Opin Pulm Med. 2012;18(1):1-5.

23. Ledford DK. Omalizumab: overview of pharmacology and efficacy in asthma. Expert Opin Biol Ther. 2009;9(7):933-943.

24. Spector SL, Tan RA. Effect of omalizumab on patients with chronic urticaria. Ann Allergy Asthma Immunol. 2007;99(2):190-193.

25. Kaplan AP, Joseph K, Maykut RJ, Geba GP, Zeldin RK. Treatment of chronic autoimmune urticaria with omalizumab. J Allergy Clin Immunol. 2008;122(3):569-573.

26. Callejas-Rubio JL, Sánchez-Cano D, Lara MA, Ortego-Centeno N. Omalizumab as a therapeutic alternative for chronic urticaria. Ann Allergy Asthma Immunol. 2008;101(5):556.

27. Vestergaard C, Deleuran M. Two cases of severe refractory chronic idiopathic urticaria treated with omalizumab. Acta Derm Venereol. 2010;90:443-444.

28. Magerl M, Staubach P, Altrichter S, et al. Effective treatment of therapyresistant chronic spontaneous urticaria with omalizumab. J Allergy Clin Immunol. 2010;126(3):665-666.

29. Saini S, Rosen KE, Hsieh HJ, et al. A randomized, placebo-controlled, dose-ranging study of single-dose omalizumab in patients with $\mathrm{H}(1)$ antihistamine-refractory chronic idiopathic urticaria. J Allergy Clin Immunol. 2011;128(3):567-573.

30. Labrador-Horrillo M, Valero A, Velasco M, et al. Efficacy of omalizumab in chronic spontaneous urticaria refractory to conventional therapy: analysis of 110 patients in real-life practice. Expert Opin Biol Ther. 2013;13(9):1225-1228.
31. Metz M, Ohanyan T, Church MK, Maurer M. Retreatment with omalizumab results in rapid remission in chronic spontaneous and inducible urticaria. JAMA Dermatol. 2014;150:288.

32. McCormack P. Omalizumab: a review of its use in patients with chronic spontaneous urticaria. Drugs. 2014;74(14):1693-1699.

33. Chang TW, Chen C, Lin C-JJ, Metz M, Church MK, Maurer M. The potential pharmacologic mechanisms of omalizumab in patients with chronic spontaneous urticaria. J Allergy Clin Immunol. 2015; 135(2):337-342.

34. MacGlashan DW Jr, Bochner BS, Adelman DC, et al. Down-regulation of Fc(epsilon)RI expression on human basophils during in vivo treatment of atopic patients with anti-IgE antibody. J Immunol. 1997;158(3):1438-1445.

35. Noga O, Hanf G, Brachmann I, et al. Effect of omalizumab treatment on peripheral eosinophil and T-lymphocyte function in patients with allergic asthma. J Allergy Clin Immunol. 2006;117:1493-1499.

36. Namazy J, Cabana MD, Scheuerle AE, et al. The xolair pregnancy registry (EXPECT): the safety of omalizumab use during pregnancy. J Allergy Clin Immunol. 2015;135(2):407-412.

37. Vieira dos Santos R, Locks Bidese B, Rabello de Souza J, Maurer M. Effects of omalizumab in a patient with three types of chronic urticaria. Br J Dermatol. 2014;170:469-471.

38. Ghazanfar MN, Thomsen SF. Successful and safe treatment of chronic spontaneous urticaria with omalizumab in a woman during two consecutive pregnancies. Case Rep Med. 2015;2015:368053.

39. Church MK, Weller K, Stock P, Maurer M. Chronic spontaneous urticaria in children: itching for insight. Pediatr Allergy Immunol. 2011; 22(1 pt 1):1-8
Drug Design, Development and Therapy

\section{Publish your work in this journal}

Drug Design, Development and Therapy is an international, peerreviewed open-access journal that spans the spectrum of drug design and development through to clinical applications. Clinical outcomes, patient safety, and programs for the development and effective, safe, and sustained use of medicines are a feature of the journal, which

\section{Dovepress}

has also been accepted for indexing on PubMed Central. The manuscript management system is completely online and includes a very quick and fair peer-review system, which is all easy to use. Visit http://www.dovepress.com/testimonials.php to read real quotes from published authors.

Submit your manuscript here: http://www.dovepress.com/drug-design-development-and-therapy-journal 